\title{
History lessons
}

\section{Late night musings on our fatal flaws and our children}

$\mathrm{T}$ The experiences of September 11, 2001 have reminded us of the world as it is, not as we wish it to be. Our sincere sympathies go out to the survivors and victims' families of the attacks in New York and Washington. The event was so significant that it should be remembered on the pages of a medical journal as well as in all our media. Much has been learned about why people hate and how dangerous it is to have only one point of view, and that believing others to be wrong demands that one take violent action. We need to be reminded that we as humans are flawed, and that one of those great defects is our propensity to see the world as them and $u s$. We are essentially war-like and these impulses need to be controlled, often by threat. We think of the 20th century as one long peace, but this is an illusion. We now think of peace as the absence of nuclear weapons being used since 1945 . The fact is that we have nothing to be proud of. The 20th century was the bloodiest century in history, made all the more fearful because weapons of mass destruction were produced. The recent events have put our thinking into high gear and removed us from the fool's paradise we have lived in. Our first order of business should be the elimination of all nuclear weapons because it is not enough to trust any government or group not to use them.

We have been reminded just how tenuous peace is, and how we need security to go about our daily lives.

In essence, this is a human nature story. We like to believe that human nature is improving slowly as the centuries go by. I'd like to think that this is true, but reading war history tells me otherwise because we humans have a fatal flaw, and that is that some of us think that war is exciting and necessary. It seems that we avoid talking about this issue and persist in our dreamy state, confusing what we want to believe (that our nature is improving) with the human tragedy that we see.

We surgeons know a lot about war. Many surgical specialties began in wartime in response to the horrific needs of young, wounded men and women. Sometimes great surgical advances occur in wartime, so we are tempted to think that war has its good side. But we have short memories. We tend to forget how precious peace is a few years after the war ends. Thus, there is the necessity of always remembering.

A war seems to start when groups see themselves as superior to other groups of people. For this reason, travelling at a young age is a great prevention of war because young people then further understand the world and see other people as in- dividuals, much like themselves. Psychopathic leaders who attain power are very hard to unseat by democratic processes, so there must be other ways to get rid of them. Thus, the great lesson of history is being vigilant and involved in democracy as an individual citizen. Democracy is so precious that it must be used or lost.

We also tend to think that the ideas and policies of our largest institutions are right, but we are going to see that the World Health Organization was overly optimistic about human nature when they said that we did not need smallpox vaccinations. Millions of people are now vulnerable to a relatively simple attack.

War also starts when one group or the other thinks that there are absolutely no other choices than war, and that there is no other choice to maintain pride and preserve the group.

During war, murder becomes more expedient than incarceration, and death can become preferable to life. War then must be a form of mass psychosis that deceptively gives meaning to life or hopelessness. We tend to have short memories. We forget who started the war and who is defensive, aiming to defeat the aggressor. Being attacked leaves one with no choice but to enter into a defensive war and, thus, the cycle begins. It also seems that we go to war too quickly to avoid missing a window of opportunity and to avoid being seen as being weak or irresolute. Why not wait and assess the situation before responding to an attack? Why not wait, and make certain that the extent and size of the problem are fully understood?

The present war with terrorists is an example of a different idea in conflict. It is committed and seems ideologically pure - a few people are dedicated to a cause in which they use the foe's strength against him. Like the Kamikaze, they are honoured to die to achieve greatness for the group, which is their sole reason for living and dying. But consider that their goal might not just be terror, but something different and wider. Perhaps their goal is to amalgamate their fragmented groups into a larger coalition against us as the common enemy. Perhaps they need us as an enemy. Perhaps the terrorist's goal is to take over the government of a rich country and use that revenue to further the cause of terrorism or unite many groups that are now fragmented.

Perhaps war occurs when people do not have the patience for slow change, for there is usually fast change in war for better or worse, depending on who you are. 
World War II has been blamed on the Allies who imposed the rigid Treaty of Versailles on Germany. This is an interesting view because it blames the victorious side as the cause of the next war. After World War II, the Allies launched a major welfare and rebuilding plan to reconstruct defeated countries. This reconstruction will be done this time too, but countries adjacent should also contribute in a major way. Many countries do not have a tradition of humanitarian service and look upon such urges with suspicion. Voluntary organizations should be encouraged to show the reasons for their gifts so that volunteering for the poor and needy becomes a tradition among all people. We need to remember that the economy, and producing broadly based wealth, underlies democracy and peace.

We surgeons see lives changed every day by trauma and fortune. It is easy for us to become fixers of other people's problems and be satisfied with that. It is also easy to become focused on detail and ignore the bigger picture, but we need to do something more. We are in a unique situation to understand the good and bad aspects of human nature, particularly how and why wars occur. We need to speak and act to prevent war, and explain that there have to be other alternatives because it is our children who fight the wars. We need to remember that there are no good wars. We need to discuss what we remember on Rememberance Day, November 11th each year. We need to remember not only the sacrifice but our flawed nature that we all share that sent us to war in the first place.

We surgeons know how war devastates lives. Though we admire heroism, we need to prevent the need for such heroism. My reading of war history tells me that human nature has changed little over the centuries and we must be vigilant regarding its most dangerous expressions. We must not confuse our technical and social advancement with our nature.

We Canadians are peacekeepers, but there must first be a peace to keep.

If we must fight defensively we will, and we will win. We will be the most steadfast, committed and prepared warriors anyone has known.

That is also our history in Canada.

I like what a friend of mine said recently, "Billions for defense, but not one cent for tribute." 